\title{
Modernization of Pedagogical Education Content and Principles of Developing a Modular Educational Program for a Teacher-Researcher Training
}

\author{
Sholpan Alimova, Natalya M. Ushakova \\ Department of Psychology and Pedagogy, S. Toraighyrov Pavlodar State University, Lomov St., 64, \\ Pavlodar, Kazakhstan
}

\begin{abstract}
This article reveals the analysis of domestic and foreign experience in the development of an educational program for a teacher-researcher training. Within the framework of the competencebased approach it makes possible to formulate a number of positions regarding the status of an "educational program" and five principles for developing a modular educational program for undergraduate students, which also includes the formation of future teachers' research competencies.

The experimental work was realized on the basis of scientific literature analysis, tests, questionnaires. Statistical data processing was accomplished by SPSS Statistics Program, moreover, the authors applied the Mann-Whitney U-test.
\end{abstract}

Keywords - educational program, competence-based approach, research competency, teacher-researcher.

\section{Introduction}

Analysis of an educational program's role for a teacher-researcher training in domestic and foreign education allows us to single out a number of

DOI: $10.18421 /$ TEM94-56

https://doi.org/10.18421/TEM94-56

Corresponding author: Sholpan Alimova,

S. Toraighyrov Pavlodar State University, Lomov St., 64, Pavlodar, the Republic of Kazakhstan.

Email: sholpan alimova@mail.ru

Received: 13 August 2020.

Revised: 04 November 2020.

Accepted: 09 November 2020.

Published: 27 November 2020.

(c) BY-NC-ND (C) 2020 Sholpan Alimova \& Natalya M. Ushakova; published by UIKTEN. This work is licensed under the Creative Commons AttributionNonCommercial-NoDerivs 4.0 License.

The article is published with Open Access at www.temjournal.com guidelines that are significant for the system of higher pedagogical education.

In the area of the procedure for establishing an educational program for a teacher-researcher training as a state norm, the levels of document approvals are presented, in all countries the national (federal) parliament approves general goals and principles of education, and defines the framework that provides educational space. General requirements for certification of qualification category "teacherresearcher" include such professional competencies as having the skills of researching a lesson and developing assessment tools, ensuring the development of students' research skills, determining a development strategy in the teaching community. Nowadays, a qualitative teacher training that is focused on the competence-based approach in education is very relevant.

Goals and standardized requirements, a monitoring and evaluation system are set at the state level, proposed standards and conditions guarantee the implementation of a competence-based approach. A research function of a teacher is the ability to plan and conduct research of the educational environment independently, knowing the research methods in pedagogy. In the State Compulsory Education Standard of the Republic of Kazakhstan, the requirements for a research competency as one of the results of mastering a bachelor's program are described on the basis of Dublin descriptors. A research competency is expressed in the ability of applying knowledge and understanding at a professional level; formulating arguments and solve problems of the studied area; collecting and interpreting information to make judgments, taking into account social, ethical and scientific considerations; having lifelong learning skills; knowing the methods of scientific research and academic writing and applying them in the studied area. 
Decentralization of education in the Republic of Kazakhstan increases the responsibility of higher education institutions for the quality of educational content. Educational institutions are responsible for the development of educational programs, curricula, teaching aids, defining the content of education, the sequence of training courses, the choice of teaching methods and technologies.

\section{Literature Review}

New requirements for education have led to a new definition of a specialist. Until recently the qualification characteristic of a specialist had a list of knowledge and skills, but now competencies and communication skills are crucial, a specialist has to be "with academic competences and social skills required for teaching groups, establishing a positive contact with pupils" [1].

Therefore, we can proceed from the statement that modern pedagogical education should be focused on the formation of a personality that is adequate to the content of professional activity. The object of a person's professional development is his/her integral characteristics: competency, social and professional orientation, significant professional qualities, psychophysiological properties. This understanding of the educational goal leads scientists to the opinion of defining a unified methodological basis for professional standards, educational standards and educational programs. The complexity of its establishment is due to the fact that higher educational institutions develop educational programs for higher education independently. Consequently, it is necessary to refer to the influence of an educational program in the educational space. An analysis of scientific publications presented in Scopus database over the past three years shows different approaches to this area.

In the area of influence with regard to an educational program for a teacher-researcher training, it has been established that in most countries the concept of "educational program for a specialist training" is used in official documents, in others countries there is not any concept in official documents, except in education; the educational program of the specialty or its equivalent (goals, curriculum) is presented as an indicator of the level of education development and a measure of individual responsibility. The area of the educational program is normative and administrative, the object of regulation is the content of education; the educational program of a teacher training is considered as a system-forming and defining document of the educational process organization.

The following aspects of the educational space that affect an educational program within the competence-based approach in education are examined in this study.

The first aspect of research in the educational space is determined by the new understanding of qualifications as professional competency. This is reflected in the competence models of a specialist and State Compulsory Education Standard of higher education, created on the basis of these models. As Walkington H. noted [2], "students as researchers in a higher education context mean a pedagogic approach to supporting students in their engagement with undergraduate research within and/or beyond the formal curriculum with the aim of furthering their own knowledge and understanding, and in some cases contributing to, the broader knowledge base of their discipline". The research competency model can consist of two types: educational and scientific, which differ in the types of skills.

The determination of research competency types is due to the requirements of continuous scientific work of students at 6-8 qualification levels of education, specified in the European Qualifications Framework [3] and the National Qualifications Framework for the higher education of the Republic of Kazakhstan [4]. The levels of implementation of a research competency are studied in higher education [5]. They proved experimentally that "educational practice teacher researcher competence forms in two levels: theoretical at the university and practical - when future teachers perform pedagogical internship in educational institutions". Scientists point out that the main goal of pedagogical practice is "to evaluate student personal readiness for this activity and study process favorableness to scientist career choice" [5]. The implementation of research competency in the Master of Education program presents by some scientists that develop the idea of continuous research practice and come to the conclusion that "pedagogical research cannot be a desk study based on secondary information/data obtained in the course of other studies. The pedagogical research should be based on primary information - it is data obtained as a result of a specially organized and conducted experiment or pilot study in the real pedagogical conditions" [6].

The process will be most effective if in learning communities "students take two or more linked courses as a group and work closely with one another and with their professors" [7].

Kazakhstani scientists consider the learning process to be inseparable from research, since research activities are aimed at creating conditions for comprehensive development and implementation of students' scientific potential of at the university and "one of the pedagogical condition of research competence formation is the creation of an educational research community of students" [8]. 
Thus, in the educational space a new understanding of a teacher's qualifications is associated with both professional competency and research competency, which are formed at three levels of education and developed in the real educational process.

The second aspect of the educational space study is associated with the development of a specialist model, which is understood as the norm or standard of social necessary requirements on the part of production, social or individual to the properties of a specialist, or the norm of requirements for a specialist's qualifications and competencies.

The third aspect of research in the educational space examines the relationship between competencies and qualifications in an educational program. Thus, scientists [9] believe that, along with competencies, an educational program of a specialty should include and describe qualifications, that is assigned to a graduate of a university, and a mechanism for the assessment, since a qualification is the level of training, preparedness for the competent performance of a certain type of activity according to the obtained specialties. The norms set by the educational program should be clearly defined, evaluated and verified.

In the area of the composition and structure of an educational program for a teacher-researcher training as a normative document: the educational program of the specialty is implemented through a system of requirements, criteria, guidelines presented in educational materials, it is part of the curriculum (program, recommendations for teachers), moreover, it includes syllabus.

Most scientists reveal a modular structure of an educational program and the structure of the catalog of elective disciplines. It is necessary to provide students with a choice in the study of elective disciplines, which include research. Russian scientist emphasizes [10] that "the development of electives or elective disciplines, including a basic module aimed at solving key problems and creating a system of solutions to improve the social status of a teacher in a region, and a variant module aimed at training students in various types of professional activity and research activity".

There should be the proportion between the disciplines of the compulsory component and the disciplines of the elective component. In scientist's opinion "it is necessary to attract resources not only from the disciplines of the research module, but from other academic disciplines and practices. Each academic discipline has its own content and organizational resource (assignments, tests, term papers) that can be used in the organization of pedagogical research" [6]. Another scientist states about the content resource of the academic discipline, it is necessary "to continue the work on the introduction of modern methods of research into all academic studies, to increase the students' creative activity in the process of learning, to ensure the thematic unity of learning and research and scientific-research work of students at different courses" [11].

Moreover, some professors pay attention to the forms of organization of training that "lessons with elements of research activity are of great interest to students, and this in their turn motivates the learning process" [12].

Thus, in order to consider an educational program of a teacher training as a system-forming and defining document of the educational process organization, it should be included in the educational space. It should be taken into account that the formation of a research competency is associated with the elements characteristics of the education content and the structure of an educational program. However, it is necessary to determine the status, composition and structure, system of requirements, criteria, guidelines of an educational program. This fact determined the aim of our study.

The aim of the study is to describe the basics of modernization of pedagogical education content and principles of developing a modular educational program for a teacher-researcher training.

\section{Research Methods}

Content analysis was aimed at systematizing regulatory documents, standards, theoretical and methodological literature on the studied problem. Questionnaires and tests were used as a diagnostic tool to identify the level of students' research competency formation. Statistical data processing was accomplished by SPSS Statistics Program. The authors applied the Mann-Whitney U-test for mathematical reliability of the experiment and to prove the absence of differences in levels between the control and experimental groups on a preliminary cut.

For the experimental and control selection of students, authors analyzed students' level of a research competency formation. 71 undergraduate students took part in the formative experiment. The experimental group (EG) consisted of 36 students, and there were 35 students in the control group (CG). During the experiment, educational programs of professional training which are implemented at the Pavlodar State Pedagogical University was studied in details. 


\section{Results}

The results of monitoring the formation of students' research competency of both experimental and control groups on preliminary and checkup tests, based on diagnostic tools, are presented in Tables 1 and 2 .

Table 1. Results of monitoring the formation of students' research competency (test of knowledge and understanding of scientific methods and research techniques)

\begin{tabular}{|c|c|c|c|c|}
\hline Test & 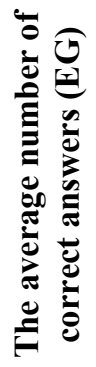 & 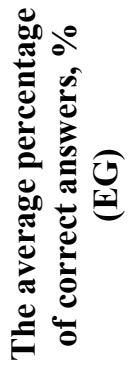 & 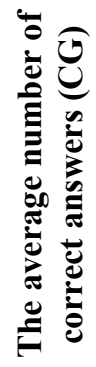 &  \\
\hline Preliminary & 10 & 62,5 & 11 & 68,75 \\
\hline Checkup test & 14 & 87,5 & 12 & 75 \\
\hline
\end{tabular}

The test results revealed positive dynamics and a significant increase in correct answers by $25 \%$ among the respondents from EG after the formative experiment. According to the same test, an increase in correct answers of the students from CG was determined by only $6.25 \%$, which proves the necessity to include an interdisciplinary module in the educational process to form a research competency of future teachers.

Table 2. Questionnaire "Assessment of students' research competency formation"

\begin{tabular}{|c|c|c|c|c|c|}
\hline \multirow{2}{*}{ 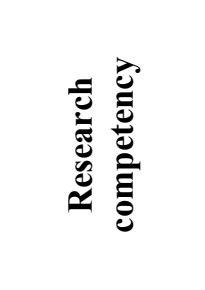 } & \multirow{2}{*}{ 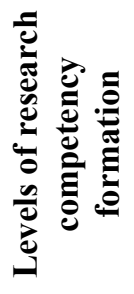 } & \multicolumn{2}{|c|}{$\begin{array}{c}\text { Ascertaining } \\
\text { stage }\end{array}$} & \multicolumn{2}{|c|}{$\begin{array}{c}\text { Formative } \\
\text { stage }\end{array}$} \\
\hline & & $\dot{0}^{0}$ & $\underbrace{0}$ & $\dot{\theta}^{0}$ & $\dot{0}^{0}$ \\
\hline \multirow{3}{*}{$\begin{array}{l}\text { Ability to use } \\
\text { research } \\
\text { methods } \\
\text { correctly }\end{array}$} & high & 11,1 & 14,3 & 61,3 & 20 \\
\hline & average & 66,7 & 62,8 & 33,1 & 68,6 \\
\hline & low & 22,2 & 22,9 & 5,6 & 11,4 \\
\hline \multirow{3}{*}{$\begin{array}{l}\text { Ability to } \\
\text { implement } \\
\text { various } \\
\text { procedures of } \\
\text { research } \\
\text { activities }\end{array}$} & high & 22,9 & 23,2 & 79,9 & 23,2 \\
\hline & average & 62,1 & 63,6 & 20,1 & 72,3 \\
\hline & low & 15 & 13,2 & 0 & 4,5 \\
\hline \multirow{3}{*}{$\begin{array}{l}\text { Ability to do } \\
\text { research } \\
\text { activities } \\
\text { independently }\end{array}$} & high & 22,2 & 20 & 75,4 & 22,9 \\
\hline & average & 75 & 74,3 & 24,6 & 77,1 \\
\hline & low & 2,8 & 5,7 & 0 & 0 \\
\hline
\end{tabular}

To verify statistically significant differences between the results of the ascertaining and formative stages of the experiment the authors used the MannWhitney U-test. This criterion proves the absence of differences in the levels of the studied features between the experimental and control groups on the preliminary cut [13].

The criterion statistics has the form as:

$$
U=n_{1} \cdot n_{2}+\frac{n_{x} \cdot\left(n_{x}+1\right)}{2}-R_{x}
$$

where $n_{1}$ is the number of elements in the first selection, $n_{2}$ is the number of elements in the second selection, $R_{x}$ - the largest of the two rank sums of both first and second selections.

Using the principle of ranking, we get a table of ranks. The sum of the ranks for EG is 1308 , for $\mathrm{CG}-$ 1248. The largest sum by $R_{x}$ is 1308 .

Here are two hypotheses to be formulated:

H0: EG does not exceed CG in terms of the level of a research competency formation;

H1: $E G$ exceeds $C G$ in terms of the level of a research competency formation;

To determine the value "Ability to use research methods correctly" the formula $U_{e m p}$ is considered:

$$
U_{E G}=618 \text {. }
$$

To determine the value of $U_{C G}$ the same formula is used:

$$
U_{C G}=678 \text {. }
$$

The correctness of calculating the Mann-Whitney U-test is checked by this formula : $U_{E G}+U_{C G}=n_{1}$. $n_{2}$.

The critical value of the criterion is calculated using the formula in Microsoft Excel. The significance level $\alpha$ is equal to 0,01 . For the significance level $\alpha=0,01$ the calculated value of the criterion $U_{e m p}$ is 618 , while the critical value $U_{\text {crit }}(0,01)$ is 534. So, $618>534$. We can state significant differences if $U_{e m p} \leq U_{\text {crit }}$.

Since $U_{e m p}>U_{c r i t}$, therefore, the selections have statistically insignificant differences and with a probability of $99 \%$ of the $\mathrm{H} 0$ that $\mathrm{EG}$ and $\mathrm{CG}$ are homogeneous. Thus, at the ascertaining stage, EG does not exceed CG in terms of the level of research competencies formation "Ability to use research methods correctly".

Also, CG exceeds EG in terms of the level of a research competency formation "Ability to implement various procedures of research activities" and confirms the alternative hypothesis.

In the same order as the above calculations, we identified statistically significant differences in the ascertaining stage "Ability to do research activities independently". In this research competency, EG is not meaningfully, but it exceeds CG. 
After the conducted formative experiment, the data in the table indicate significant changes in the level of a research competency formation of students from EG. The CG also have some positive changes, mainly at the average level. The proportion of students with a high level after the formative stage and experimental activity is the competency "Ability to implement various procedures of research activities" (EG - 79.9\%, CG - 23.2\%), then goes "Ability to do research activities independently" (EG $-75.4 \%, \mathrm{KG}-22.9 \%$ ), and the last one is "Ability to use research methods correctly" (EG-61.3\%, CG $20 \%$ ).

Thus, the percentage of the dynamics of a research competency formation among the respondents from EG is higher in comparison with $\mathrm{CG}$.

\section{Discussion}

The description of the basics of modernization regarding pedagogical education content and the principles of developing an educational program for a teacher-researcher training is carried out in two areas: in the area of modernization of education content and in the area of the composition and structure of an educational program for a teacherresearcher training as a normative document.

In the area of modernization of education content and educational programs, we formulated a number of positions regarding the status of an educational program.

The philosophical basics of an educational program of the specialty are based on modern ideas about the conditions of human genesis in a changing world. The new development of civilization requires a new type of specialist - a "competence specialist", consequently, new units of educational content. "Competence is often used to characterize the potential opportunities for a specialist to get a job in a labor market" [14]. Therefore, competencies have qualification characteristics in the form of a process of actions, and not a list of "knowledge and skills". At the same time, it should be clarified that our study uses generally accepted interpretation of a competency as the ability of practical usage of knowledge, skills and abilities acquired in the learning process. As you know, at the beginning of the 21st century, the European Union adopted the types of competencies and Dublin descriptors in 2004, that is, a model for describing each type of competency by the level of education. In the last decade, these changes have covered not only the sphere of higher education, but also pedagogy as a scientific branch where the pedagogical paradigm is changing. Our research shows that the traditional pedagogical paradigm correlates with new achievements in the manner shown in Table 3.
Table 3. Competency - a new type of educational content

\begin{tabular}{|c|c|}
\hline $\begin{array}{c}\text { Traditional pedagogical } \\
\text { paradigm }\end{array}$ & $\begin{array}{c}\text { Competence pedagogical } \\
\text { paradigm }\end{array}$ \\
\hline $\begin{array}{c}\text { Type of educational } \\
\text { content }\end{array}$ & Dompetencies \\
\hline $\begin{array}{c}\text { Units of educational } \\
\text { content }\end{array}$ & $\begin{array}{c}\text { Dublin descriptors by the } \\
\text { level of education }\end{array}$ \\
\hline $\begin{array}{c}\text { Qualification } \\
\text { characteristic }\end{array}$ & Educational level \\
\hline Education result
\end{tabular}

In the methodological explanation, along with the philosophical one, it is necessary to take into account an economic aspect of the development of an educational program, namely the focus on solving the problem of interaction between education, science and economics, solving the problem of compulsory and individual in education.

An integral role in the development of the educational program of the specialty should belong to pedagogy, where education is a special subject of research. The mandatory minimum of the educational content for a teacher-researcher training includes knowledge, skills necessary to perform professional functions, creativity, the ability to adapt to changing conditions, a wide profile of training, which allows to coordinate and manage various parts of professional activity.

A student's personal qualities are expressed in the ability to apply knowledge and understanding at a professional level, the ability to use research methods correctly, the ability to implement various procedures of research activities, and the ability to do research activities independently. These include moral and ethical, and physiological competencies.

Pedagogical basics for an educational program development of the specialty is associated with the following area.

The area of the composition and structure of the educational program for a teacher-researcher training as a normative document means the normativity of an educational program as a document which is implemented through a system of requirements, criteria, guidelines presented in educational materials.

The first requirement for the educational program of the specialty is its composition. According to the results of the experimental work, 11 documents were included into the educational program: an explanatory note, a specialty passport, a graduate's qualification characteristics, the content of a specialty program, a description of modules/academic disciplines, a catalog of elective disciplines, a structural and logical scheme of training, including individual learning paths, a list from the catalog elective disciplines, an academic calendar of the educational process for the full period 
of study, a summary table in credits, a working curriculum of the specialty for the full period of study.

The second requirement for the description is associated with the mechanism for the development of these documents, which is carried out along the line of causal links: National qualifications framework of the Republic of Kazakhstan (levels 68) - Sectoral framework of the Republic of Kazakhstan - Professional standard - State educational standard of higher and postgraduate education - Model of a specialist of a certain level of training - Educational program of a certain level of training and specialty profile. The process of developing an educational program is based on five principles and assessment criteria.

The first principle: the correlation of educational program with the labor market is the basis for determining the specifics of educational program, mainly taking into account the directions at the level of employers' needs and labor market. In experimental work, it is realized through particular requirements: assembling a team; explaining of activity areas and specialty profile, creating a competence-based model of a graduate in the specialty passport. The functions of the educational program developers are presented in table 4.

Table 4. Functions of the educational program developers

\begin{tabular}{|l|l|l|}
\hline \multicolumn{1}{|c|}{$\begin{array}{c}\text { Employers' } \\
\text { functions }\end{array}$} & $\begin{array}{l}\text { Teaching staff } \\
\text { functions }\end{array}$ & \multicolumn{1}{|c|}{$\begin{array}{c}\text { Student / } \\
\text { graduate } \\
\text { functions }\end{array}$} \\
\hline $\begin{array}{l}\text { Determination of } \\
\text { profession } \\
\text { requirements } \\
\text { level for the } \\
\text { educational } \\
\text { program }\end{array}$ & $\begin{array}{l}\text { Determination } \\
\text { of competencies } \\
\text { and their list for } \\
\text { the educational } \\
\text { program }\end{array}$ & $\begin{array}{l}\text { Determination a } \\
\text { graduate's } \\
\text { personal } \\
\text { qualities }\end{array}$ \\
\hline $\begin{array}{l}\text { Consideration of } \\
\text { industry forecasts } \\
\text { for the } \\
\text { educational } \\
\text { program profile }\end{array}$ & $\begin{array}{l}\text { Determination } \\
\text { of learning } \\
\text { outcomes for } \\
\text { each } \\
\text { competency }\end{array}$ & $\begin{array}{l}\text { Establishment } \\
\text { of additional } \\
\text { competencies } \\
\text { corresponding } \\
\text { to the specifics } \\
\text { of the } \\
\text { educational } \\
\text { program profile }\end{array}$ \\
\hline $\begin{array}{l}\text { Consideration of } \\
\text { regional market } \\
\text { needs for the } \\
\text { educational } \\
\text { program profile }\end{array}$ & $\begin{array}{l}\text { Description of } \\
\text { the required } \\
\text { level of each } \\
\text { competency } \\
\text { development }\end{array}$ & $\begin{array}{l}\text { Establishment } \\
\text { of basic } \\
\text { professional } \\
\text { competencies }\end{array}$ \\
\hline $\begin{array}{l}\text { Implementation } \\
\text { of an expert } \\
\text { assessment of the } \\
\text { educational } \\
\text { program }\end{array}$ & $\begin{array}{l}\text { Description of } \\
\text { the relationship } \\
\text { between } \\
\text { bachelor's and } \\
\text { master's } \\
\text { degrees }\end{array}$ & $\begin{array}{l}\text { Educational } \\
\text { program profile } \\
\text { selection }\end{array}$ \\
\hline
\end{tabular}

A specialty passport contains the qualification characteristics of a bachelor. It is formed by three stakeholders: government, corporate partners, and an academic community. Practical activities of educational developers made it possible to establish the rules for choosing a specialty profile (Table 5).

Table 5. Rules for choosing an educational program profile

\begin{tabular}{|l|l|}
\hline $\begin{array}{c}\text { Confirm a social order } \\
\text { for a modular } \\
\text { educational program: }\end{array}$ & \multicolumn{1}{c|}{$\begin{array}{c}\text { Confirm a modular } \\
\text { educational program } \\
\text { profile: }\end{array}$} \\
\hline $\begin{array}{l}\text { 1) an agreement with } \\
\text { employers }\end{array}$ & $\begin{array}{l}\text { 1) correct and independent } \\
\text { presentation of an } \\
\text { educational profile by the } \\
\text { departments }\end{array}$ \\
\hline $\begin{array}{l}\text { 2) statistics on the regional } \\
\text { labor market }\end{array}$ & $\begin{array}{l}\text { 2) accuracy of an } \\
\text { educational profile title }\end{array}$ \\
\hline 3) employers survey & $\begin{array}{l}\text { 3) focus on the development } \\
\text { of professional competencies } \\
\text { (skills) }\end{array}$ \\
\hline $\begin{array}{l}\text { 4) an international training } \\
\text { program }\end{array}$ & $\begin{array}{l}\text { 4) a scientific, pedagogical, } \\
\text { methodological community } \\
\text { at the department }\end{array}$ \\
\hline
\end{tabular}

The criterion for the assessing an educational program is school teachers' and education and science representatives' participation in its development.

The second principle: flexibility and compliance with the changing needs of secondary education, which underlies the development of a catalog of elective disciplines. This document contains a list of educational disciplines of the elective component, a description of the content, volume and forms of midterm control. In experimental work, the disciplines of the research module are included in the catalog of elective disciplines for compulsory study.

Based on the formula for research proposed by a scientist [15], it was determined how many credits in the educational program of disciplines are involved in the formation of a research competency: $X_{\mathrm{r}}=V_{\mathrm{r} / \mathrm{n}}$, where $X_{r}$ is the number of credits, upon mastering which research competency is formed, $V_{r}$ is labor intensity of disciplines in credits, $n$ is the number of competencies. The educational program for this educational trajectory from the first to the fourth years of study includes disciplines aimed at the formation of a research competency. The disciplines as "Pedagogy" (5 credits), "New approaches in teaching a foreign language" (5 credits), "Methodology and technology for preparing students for standardized tests" (5 credits), "Social and political vocabulary" (5 credits), "Business English" (5 credits) and "English for Academic Purposes" (5 credits) in addition to a research competency form two more professional competencies. Moreover, the discipline "Fundamentals of teachers' and students' 
research activities" ( 3 credits) has been developed. As a result, we get the following calculations: $X_{\mathrm{r}}=(5$ $+5+5+5+5+5) / 3+3=13$ credits. Thus, a research competency is formed among students in a workload of 13 credits or 390 academic hours.

The criterion for assessing the educational program is monitoring and updating the catalog of elective disciplines and a variable component of the educational program. During the experiment, $25 \%$ of the disciplines of the variable part of the educational program were updated.

The third principle: conditions of satisfaction requirements of employers or the model of a specialist is associated with the conditions for filling elective disciplines with content. In the process of experimental work, three main conditions for the formation of the content of elective disciplines were reviewed:

1) social-economic development of the region (academic disciplines included in an elective component that take into consideration the specifics of social-economic development and the needs of a particular region): "Pedagogy", "Fundamentals of teachers' and students' research activities";

2) scientific communities of a higher educational institution (academic disciplines included in an elective component that take into account the existing scientific communities): "Social and political vocabulary", "Business English" and "English for academic purposes";

3) individual training of students (academic disciplines included in an elective component reflecting the individual training of a student): "New approaches in teaching a foreign language", "Methodology and technology for preparing students for standardized tests".

So, Pavlodar State Pedagogical University has established an interdisciplinary module as "Research Competency" for pedagogical specialties of the university.

The criterion for assessing the educational program is the establishment of the relationship between the educational program and the professional standard of a teacher.

The fourth principle: the structural nature of a modular curriculum of the educational program determines the mechanism for developing the structural and logical scheme of the educational program at the bachelor's level. The experimental work took into account the complexity of working curricula. The structural and logical scheme of educational program is a document that describes the principle of the logical sequence of studying academic disciplines through tools such as prerequisites and post requisites. This fact reflects the interrelation of academic disciplines in mastering the required knowledge, skills and competencies.

The structural and logical scheme of an educational program allows to fill the curriculum with the disciplines included in the competency modules. The ways for including "Research Competency" module in the curriculum of the model educational program is carried out in our study and shown in Table 6.

Table 6. Interdisciplinary module "Research competency" for pedagogical specialties of the university

\begin{tabular}{|c|c|}
\hline Title & Short description \\
\hline 1 & 2 \\
\hline $\begin{array}{l}\text { Development and } \\
\text { introduction of a new } \\
\text { discipline }\end{array}$ & $\begin{array}{l}\text { An elective discipline } \\
\text { "Fundamentals of teachers' and } \\
\text { students' research activities" has } \\
\text { been developed and introduced } \\
\text { into the educational process. The } \\
\text { content of the discipline is aimed } \\
\text { at obtaining new scientific } \\
\text { knowledge and developing future } \\
\text { teachers' professional activity on } \\
\text { a scientific basis }\end{array}$ \\
\hline $\begin{array}{l}\text { Expanding the } \\
\text { educational content of } \\
\text { existing disciplines by } \\
\text { introducing new } \\
\text { topics }\end{array}$ & $\begin{array}{l}\text { To master the structure of the } \\
\text { study, a number of topics were } \\
\text { additionally introduced for the } \\
\text { formation of research competency } \\
\text { in the discipline "Business } \\
\text { English", "Social and political } \\
\text { vocabulary" }\end{array}$ \\
\hline $\begin{array}{l}\text { Combining theoretical } \\
\text { disciplines and } \\
\text { practices based on } \\
\text { interdisciplinary } \\
\text { connections }\end{array}$ & $\begin{array}{l}\text { During pedagogical practice at } \\
\text { school students learned to } \\
\text { research lessons and develop } \\
\text { assessment tools. They worked } \\
\text { with teachers who prepare pupils } \\
\text { for subject Olympiads, } \\
\text { competitions and scientific } \\
\text { projects }\end{array}$ \\
\hline $\begin{array}{l}\text { Strengthening } \\
\text { educational and } \\
\text { research work } \\
\text { through the } \\
\text { introduction of } \\
\text { essays/papers }\end{array}$ & $\begin{array}{l}\text { The discipline "English for } \\
\text { Academic Purposes" has a } \\
\text { chapter as "Academic writing" } \\
\text { and students learn how to write } \\
\text { essays and papers }\end{array}$ \\
\hline $\begin{array}{l}\text { Organization of } \\
\text { research work outside } \\
\text { the classroom }\end{array}$ & $\begin{array}{l}\text { Scientific community at the } \\
\text { Department of Foreign } \\
\text { Languages is an association of } \\
\text { students, graduates, postgraduates } \\
\text { and teachers. The community of } \\
\text { researchers organizes research } \\
\text { activities, realizes research } \\
\text { projects, organizes seminars and } \\
\text { round tables on selected issues of } \\
\text { the humanities and pedagogical } \\
\text { sciences }\end{array}$ \\
\hline
\end{tabular}

The criterion for assessing the educational program is compliance with the competence framework of the pedagogical qualifications, given in the specialty passport. 
The fifth principle is informational. Each participant should have an access to information, the state will use the information to plan a national strategy, employers -to identify what a graduate knows and can do, teaching staff - to plan and develop educational documentation, students - to form motivation. The criterion for assessing is the openness of access.

\section{Conclusion}

This study presents the process of developing a modular educational program for a teacherresearcher training which is based on five principles. Constructed structural and logical scheme of an educational program made it possible to fill the curriculum with the disciplines included in the competency modules. A new discipline "Fundamentals of teachers' and students' research activities" has been developed, the content of education of existing disciplines has been expanded due to the introduction of new topics, theoretical disciplines and practices have been combined on the basis of interdisciplinary connections, educational research work has been strengthened due to the introduction of essays/papers and projects outside the classroom.

The statistical data of the study confirm the effectiveness of the principles within developing an educational program and the ways of including the "Research Competency" module into the curriculum. The data indicate significant changes in the level of a research competency formation of the experimental group in comparison with the control group after the conducted formative experiment. The study shows the result of effective modeling of the educational program, which is one of the main condition for improving the quality of a teacher-researcher training.

The prospects for modernizing the educational program of the specialty are aimed at solving the problem of interaction between education, science and economics, increasing the proportion of natural and social sciences, foreign languages, information technologies, increasing the role of monitoring educational activities, introducing values and competencies as a component of education.

\section{References}

[1]. European Union.(2013). Study on policy measures to improve the attractiveness of the teaching profession in Europe. Retrieved from:

https://ec.europa.eu/assets/eac/education/library/study /2013/teaching-profession2_en.pdf [accessed: 15 June 2020].

[2]. Walkington, H. (2015). Students as researchers: Supporting undergraduate research in the disciplines in higher education. York:The Higher Education Academy.

[3]. Europea, C. (2008). The European qualifications framework for lifelong learning (EQF). Luxembourg: Office for official publications of the European Communities. Retrieved from:

http://ecompetences.eu/wpcontent/uploads/2013/11/EQF_broch_2008_en.pdf. [accessed: 25 June 2020].

[4]. Council of Europe. (2020). The self-certification report on compatibility of the Kazakhstan national qualifications frameworks for the higher education with the framework for the qualifications of the European higher education area. Retrieved from: https://rm.coe.int/item-4-kazakstan-s-nqfselfsertification-report-1-/16809ca17b [accessed: 10 August 2020].

[5]. Lamanauskas, V., \& Augienè, D. (2016). Scientific research activity of students preservice teachers of sciences at university: Significance, readiness, effectiveness and career aspects. Journal of Baltic Science Education, 15, 746-758.

[6]. Emelyanova, I., Teplyakova, O., \& Boltunova, L. (2017). The Students' Research Competences Formation on the Master's Programmes in Pedagogy. European journal of contemporary education, 6(4), 700-714.

doi: 10.13187/ejced.2017.4.700.

[7]. Kuh, G. D. (2008). Excerpt from high-impact educational practices: What they are, who has access to them, and why they matter. Association of American Colleges and Universities, 14(3), 28-29.

[8]. Khan, N. N., Kolumbayeva, S. Z., Karsybayeva, R. K., Nabuova, R. A., Kurmanbekova, M. B., \& Syzdykbayeva, A. D. (2016). Evaluation of the Program Effectiveness of Research Competence Development in Prospective Elementary School Teachers. International Journal of Environmental and Science Education, 11(18), 12299-12316.

[9]. Lazarev V. S., Konoplina N. V. Deyatel'nostnyy podkhod $\mathrm{k}$ formirovaniyu soderzhaniya pedagogicheskogo obrazovaniya [Activity approach to formation of the maintenance of pedagogical education], Pedagogika [Pedagogics], 2000, No. 3, pp. 27-34. (In Russ.).

[10]. Nagovitsyn, R. S., Zamolotskikh, E. G., Potashova, I. I., \& Rybakova, L. V. (2019). Model of the System of Raising the Social Status of the Teacher in the Region on the Basis of a Pedagogical University. European journal of contemporary education, 8(2), 315-327.

doi: 10.13187/ejced.2019.2.315. 
[11]. Kurbanbekov, B. A., Turmambekov, T. A., Baizak, U. A., Saidakhmetov, P. A., Abdraimov, R. T., Bekayeva, A. E., \& Orazbayeva, K. O. (2016). Students' Experimental Research Competences in the Study of Physics. International Journal of Environmental and Science Education, 11(18), 1306913078.

[12]. Sarybayeva, A. K., Berkinbayev, M. O., Kurbanbekov, B. A., \& Berdi, D. K. (2018). The Conceptual Approach to the Development of Creative Competencies of Future Teachers in the System of Higher Pedagogical Education in Kazakhstan. European Journal of Contemporary Education, 7(4), 827-844. doi: $10.13187 /$ ejced.2018.4.827.
[13]. Sidorenko, E. V. (2003). Metody matematicheskoj obrabotki v psihologii. Methods of mathematical processing in psychology], Sankt Petersburg.

[14]. Ushakova N.M. (2017). Metodologiya i metody pedagogicheskogo issledovaniya. Pavlodar: Kereku. Retrieved from:

https://obuchalka.org/20200306118930/metodologiyai-metodi-pedagogicheskogo-issledovaniya-ushakovan-m-2017.html [accessed: 10 August 2020]. [in Russian].

[15]. Nagovitsyn, R.S., \& Golubeva, I.A. (2019). Forming future teachers' communicative competences through the student scientific society activities. Integration of Education, 23(1), 66-84.

DOI: 10.15507/1991-9468.094.023.201901.066-084 